University of Nebraska - Lincoln

DigitalCommons@University of Nebraska - Lincoln

1967

\title{
Elephant Teeth from the Atlantic Continental Shelf
}

Frank C. Whitmore Jr.

U.S. Geological Survey

K. O. Emery

Woods Hole Oceanographic Institution

H. B. S. Cooke

Dalhousie University

Donald J. P. Swift

Puerto Rico Nuclear Center

Follow this and additional works at: https://digitalcommons.unl.edu/usgsstaffpub

Part of the Earth Sciences Commons

Whitmore, Frank C. Jr.; Emery, K. O.; Cooke, H. B. S.; and Swift, Donald J. P., "Elephant Teeth from the Atlantic Continental Shelf" (1967). USGS Staff -- Published Research. 236.

https://digitalcommons.unl.edu/usgsstaffpub/236

This Article is brought to you for free and open access by the US Geological Survey at DigitalCommons@University of Nebraska - Lincoln. It has been accepted for inclusion in USGS Staff -- Published Research by an authorized administrator of DigitalCommons@University of Nebraska - Lincoln. 


\section{Reports}

\section{Elephant Teeth from the Atlantic Continental Shelf}

Abstract. Teeth of mastodons and mammoths have been recovered by fishermen from at least 40 sites on the continental shelf as deep as 120 meters. Also present are submerged shorelines, peat deposits, lagoonal shells, and relict sands. Evidently elephants and other large mammals ranged this region during the glacial stage of low sea level of the last 25,000 years.

Occasionally newspapers report the dredging by fishermen of elephant teeth from the continental shelf. Some specimens have reached museums, while others have been lost; probably many more were thrown back into the ocean or remain unreported. This compilation of known finds is intended to spur the reporting of other discoveries both past and future.

The teeth are molars and premolars from both mastodons and mammoths (Fig. 1). All offshore discoveries known to us were on the continental shelf off the northeastern United States and on its northeastward extension as Georges Bank (Fig. 2) (Table 1). The average depth of recovery is $36 \mathrm{~m}$; the maximum may be $120 \mathrm{~m}$. Some uncertainty about position and depth of the finds results from the fact that the scallop or clam trawls may be dragged several kilometers along the bottom before being hauled.

Most of the continental shelf is floored by detrital sand that is iron stained and generally coarser grained than sediments closer to the present shore (1). For these reasons the sand is considered relict from times of glacially lowered sea level. Present on or just below the surface of the sand at water depths as great as $90 \mathrm{~m}$ are shells of oysters, Crassostrea virginica (Gmelin), that lived in depths shallower than about $6 \mathrm{~m}$. Supporting evidence of former shallow water is provided by exposures of intertidal salt-marsh peat that is now as deep as $59 \mathrm{~m}$. Freshwater peats also are present. Comparison of samples of peat taken from the sea floor (eight) and from ponds ashore shows that the pollen assemblages are the same throughout (2). Radiocarbon dates for these oyster shells and peats
(Fig. 2) range back to 11,000 years ago $(3,4)$.

The fact that throughout most of the shelf the sands have remained relatively undisturbed is indicated by terraces marking former stillstands of sea level during the period when the shoreline crossed the shelf. Sands atop the northcentral part of Georges Bank and sands southeast of Cape Cod (southeast of Boston, Fig. 2), however, have been shaped into actively moving waves of sand. Foundation borings for radar towers in both areas revealed silts beneath the sands at 40 to $60 \mathrm{~m}$ below sea level; a shell in one of the silts had Other evidence of widespread stratification in the top $80 \mathrm{~m}$ beneath the continental shelf is provided by many continuous seismic profiles (6) showing the common presence of four or five reflecting horizons, each of which is probably a sediment surface produced during a low sea level associated with a glacial stage of the Pleistocene epoch. Thus the present surface of the continental shelf is not older than the Wisconsin glaciation, and much of it has received little subsequent sediment.

The evidence indicates that the present continental shelf was a broad coastal plain about 15,000 years ago, and that it gradually submerged as water from glacial ice returned to the ocean. The sea-level rise curve derived from the present water depths of the dated shells and peat differs only slightly from that of Shepard (7), which is based upon data from many places in the world. The region had been submerged during several earlier interglaciations; although the dates are poorly known, the next previous suba radiocarbon age of 11,465 years (5). mergence ended probably about 25,000 years ago. Accordingly, the outer part of the shelf must have been exposed for about 10,000 years; the inner part, about 20,000 years.

The presence of the teeth of mastodons and mammoths atop the relict sand indicates that these animals lived there during the last exposure. Evidence of the reasonableness of their presence on the shelf is the discovery of many hundreds or perhaps thousands of mastodon and mammoth bones throughout the entire eastern United States and Canada (8). Moreover, students of large Pleistocene mammals have long known that these animals must have traveled across exposed continental shelves in order to reach islands where their remains occur: notable examples are Japan, England, Mediterranean islands, Java, Sumatra, and other islands of the East Indies, and small islands off southern California. In all examples known to us the maximum present depth of the intervening strait or shelf is less than $120 \mathrm{~m}$. This depth is significant in view of a calculation, based upon estimated volume of ice, that during the Wisconsin glaciation the sea level was about $123 \mathrm{~m}$ below the present level (9). In each of the cited areas, molars or bones of elephants have been found on the sea floor. Off Japan, molars of mastodon and Elephas naumanni (Makiyama) have been dredged from a depth of $80 \mathrm{~m}$ in the strait west of Kyushu and from $90 \mathrm{~m}$ in the Inland Sea (10). In the English Channel, especially from Dogger Bank at 30 to $40 \mathrm{~m}$, bones of many Pleistocene mammals, including mammoths, have long been reported by fishermen (11). Off southern California about 1950, R. S. Dietz recovered an upper second and an upper third molar of Archidiskodon imperator Leidy at a depth of $5 \mathrm{~m}$ near Huntington Beach, and other finds of bones and molars from near Santa Barbara have been reported since 1960 by oil company divers.

The distribution pattern of elephant teeth on the sea floor off the Atlantic coast (Fig. 2) shows three concentrations: Georges Bank, off New York City, and off the mouth of Chesapeake Bay. These parts of the continental shelf are the most intensively exploited for scallops, clams, and bottom fishes, all of which require the dragging of heavy trawls along the bottom. Thus the distribution pattern merely reflects the intensity of effort or the degree of op- 
portunity for finds, as well as the extent to which specimens are rescued and passed to scientific institutions. It is notable that specimens at our disposal came from relatively few ships' captains.

Occurrence of the teeth as far as $300 \mathrm{~km}$ from the present shore and their wide distribution show that the proboscideans lived on the shelf. One may assume, therefore, that this region was well covered with land vegetation. Evidence of such vegetation is provided by the finding of twigs, seeds, and pollens of spruce, pine, and fir within peat deposits that are now deeply submerged; freshwater diatoms also are found (4). The age of this material is 11,000 years (4), and the assemblage indicates a boreal climate similar to that apparently preferred by Mammuthus primigenius (Blumenbach) in Siberia and Alaska (12).

Occurrence of a suitable diet does not, however, prove that the mammoth teeth found on the continental shelf represent the woolly mammoth. The 11 mammoth teeth available from the area between $42^{\circ} 08^{\prime}$ and $36^{\circ} 46^{\prime} \mathrm{N}$ (Fig. 2) (Table 1) are somewhat different from isolated molars of several species of Mammuthus obtained on land. We should also point out that most of the specimens recovered come from the wide-ranging mastodon Mammut americanum (Kerr), although this dominance in the collections may well reflect the greater inherent strength of mastodon molars than of the fissile plated molars of the mammoth.
Most fossil elephant specimens are isolated teeth. Tooth patterns are generically and, to some extent, specifically characteristic, and certain features of mammoth molars may have ecologic significance. Very generally, the distribution of types of mammoth teeth in the periglacial land areas of the latePleistocene epoch of North America indicates the presence of animals having fairly hypsodont teeth with many tooth plates. Such teeth typify Mammuthus primigenius (Blumenbach), the woolly mammoth, that probably ate tundra grasses and the foliage of conifers.

Generally south of the range of $M$. primigenius on land was $M$. columbi (Falconer), the Columbian mammoth. The ranges of the two species, and of

Table 1. Proboscidean teeth dredged from the sea floor off the Atlantic coast of North America. Depths in parentheses are taken from charts. Abbreviations: R, right; L, left; $\mathbf{M}^{2}$, second upper molar; $\mathrm{M}_{3}$ third lower molar; AMNH, American Museum of Natural History; ANSP, Academy of Natural Sciences, Philadelphia, Pa.; CB, collection of C. Berringer, Brielle, N.J.; HLM, collection of H. L. Milholen, 51 Linden Avenue, Hampton, Va.; LAH, collection of L. A. Huber, Div. of Shell Fisheries, S tate of New Jersey, Bivalve, N.J.; LGO, Lamont Geological Observatory, Columbia University; LS, collection of L. Samborski, 103 Coffin Avenue, New Bedford, Mass.; MCZ, Museum of Comparative Zoology, Harvard University; NL, collection of Captain N. Lepire (casts in U.S. National Museum); PU, Princeton University; USNM, U.S. Nationa1 Museum; WCC, collection of W. C. Childs, Box 301, Linwood, N.J.; WJD, collection of Mrs. W. J. Davis, Box 96, White Marsh, Va.

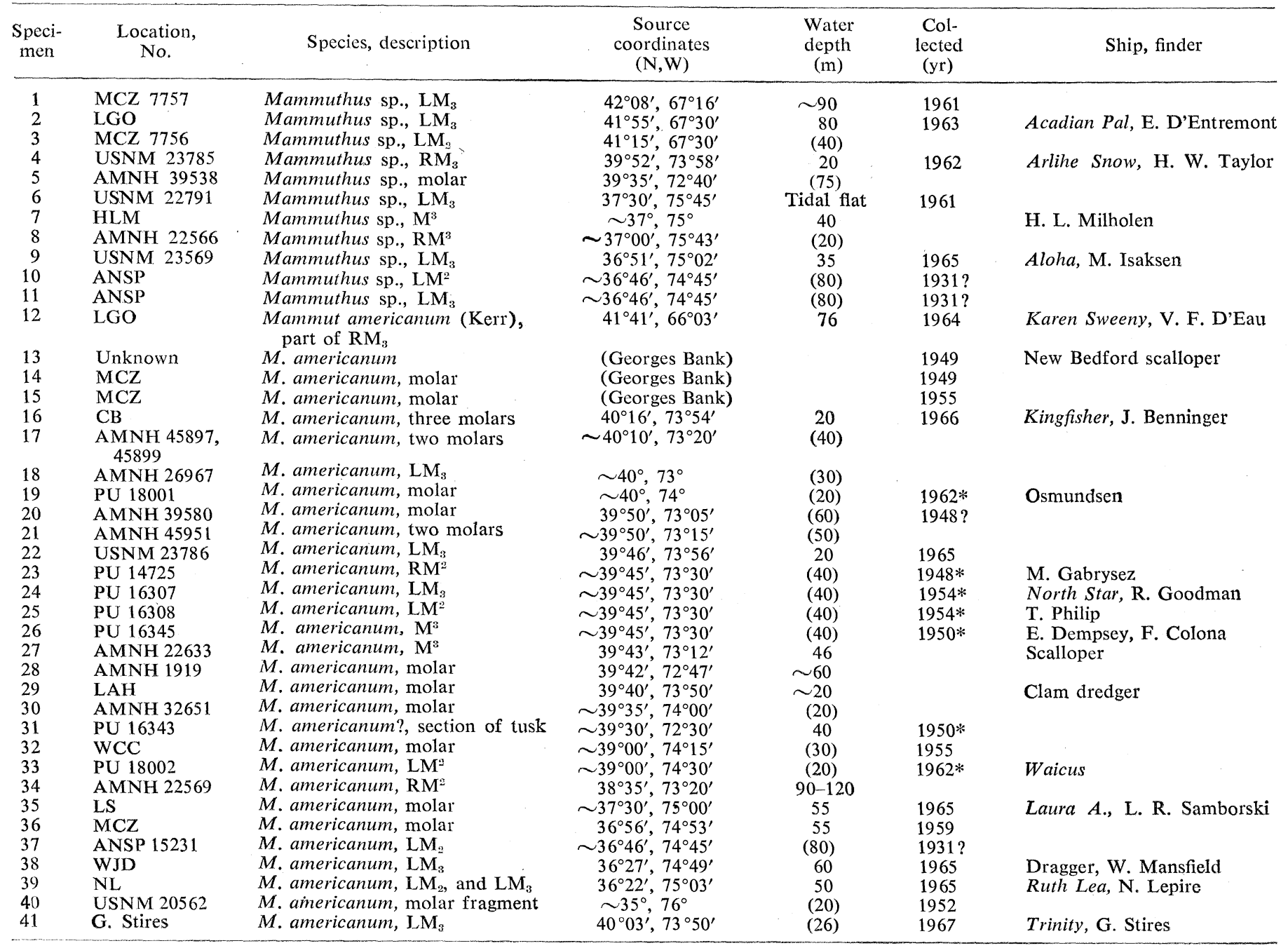

Acquisition by Princeton University. 
other species that we shall discuss, appear to have overlapped considerably if our criteria for identifying isolated teeth are sound. Mammuthus columbi had coarser teeth, with fewer plates, that can be taken to indicate browsing on softer vegetation, in accordance with distribution in a warmer climate. A species morphologically and perhaps geographically intermediate between these two was $M$. jeffersonii (Osborn). Farther south and southwest are found still coarser teeth, with fewer plates and thicker enamel; they characterize Archidiskodon imperator Leidy, the imperial mammoth.

A number of specimens of each of the four species of mammoth mentioned have been measured; the respective ranges of variation are compared graphically (Fig. 3) with the variation found in our collection from the continental shelf.

Proceeding from generalized consideration to examination of individual teeth, one finds appreciable overlap between species, one reason being individual variation, especially in thickness of dental plates. Possibly more important, although not quantitatively proved, may be the existence of races, of the species that we have just discussed, fostered by geographic or ecologic isolating factors. Some races may display characteristics of which the sum or average places them intermediate between two species. Existence of such races is reasonable in terms of our knowledge of evolutionary mechanisms, and it seems to be indicated by the geographic variation observable in North American mammoths. Observable chronologic change also was taking place in mammoth lines; it probably proceeded at a fairly rapid rate in latePleistocene time.

Thus, in the study of isolated elephant teeth when the age of the specimens is in doubt, it is difficult to distinguish between morphologic change in time and morphologic variation in space. By contrast the mastodon Mammut americanum (Kerr) is morphologically homogeneous in both time and space over a large area of northeastern North America; its remains are common in mountainous areas as well as in lowlands. Mastodons were certainly not evolving with the rapidity that characterized the mammoths.

Another obstacle to accurate classification of mammoth molars results from the mode of replacement of elephant teeth. An elephant uses essentially only four molars at a time-one 16 JUNE 1967

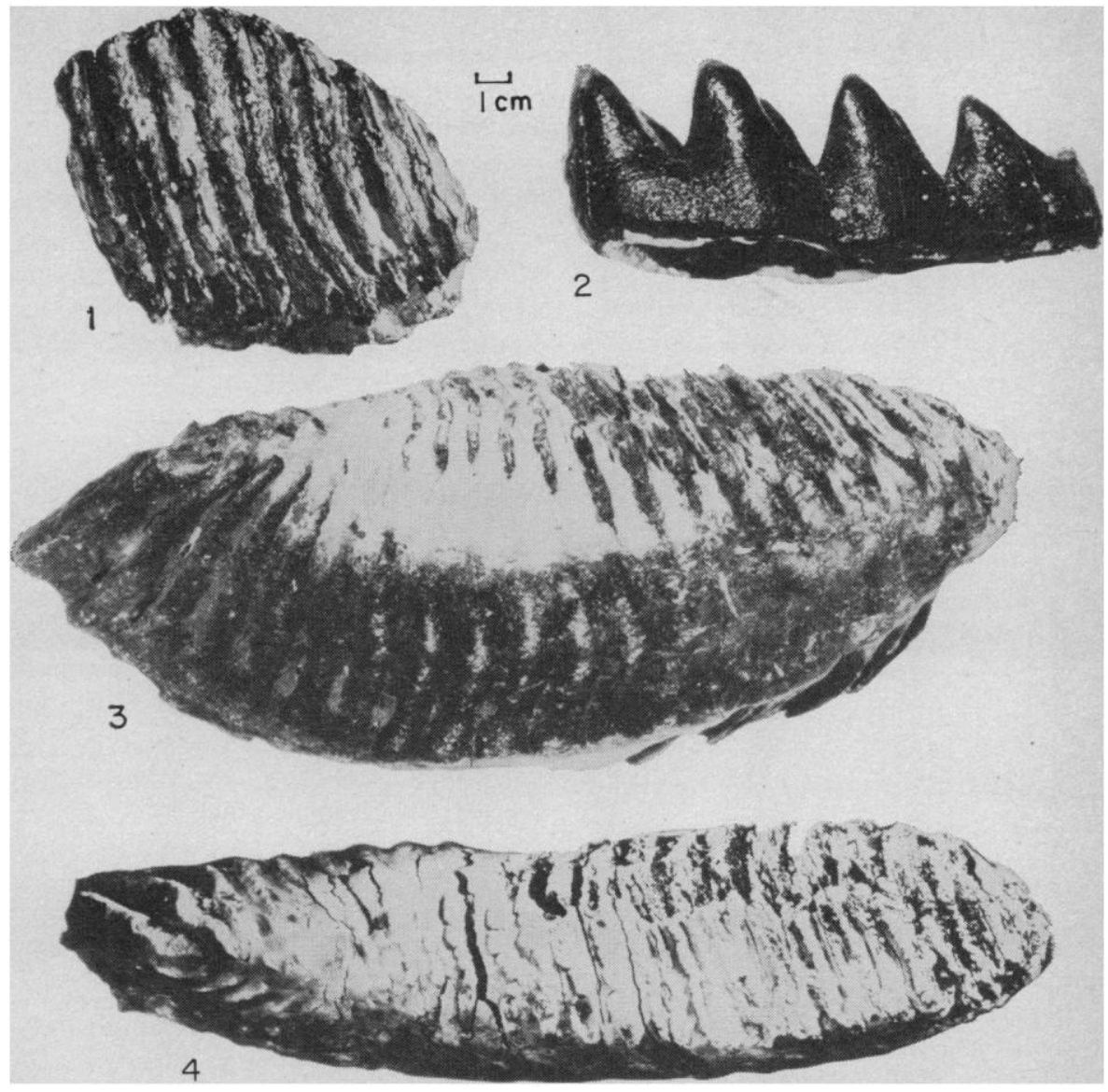

Fig. 1. Elephant teeth from the continental shelf. (1) Mammuthus sp., upper third molar (Table 1, No. 2);(2) Mammut americanum (Kerr), lower third molar (Table 1, No. 12); ( 3 and 4) Mammuthus sp., lower third molar (Table 1, No. 9), medial and crown views, respectively.

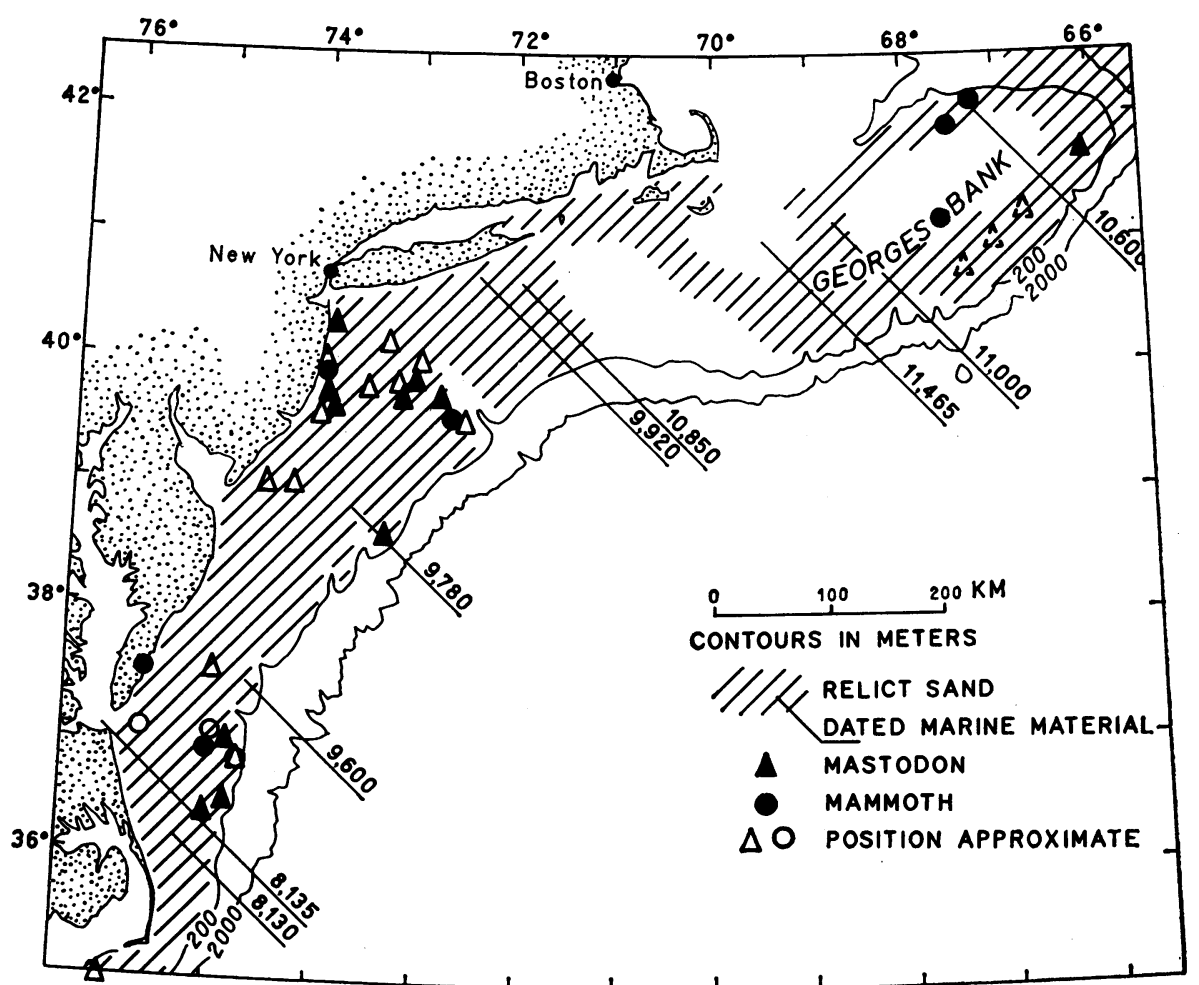

Fig. 2. Offshore sources of mastodon or mammoth teeth. Note that all sites are within the area of relict sand that also contains shallow-water oysters and intertidal peat for which radiocarbon dates are indicated. 


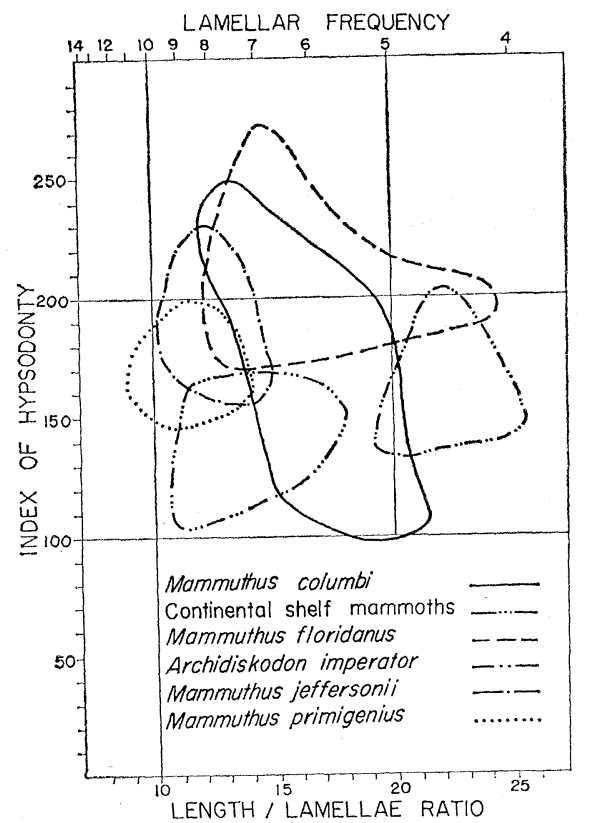

Fig. 3. Graph of mammoth-tooth dimensions, based on published measurements (16) and on measurements by two of us (F.C.W. and H.B.S.C.) of specimens in Table 1. Lamellar frequency, number of tooth plates per $100 \mathrm{~mm}$; index of hypsodonty, (height $\times 100$ )/width.

in each half of each jaw. As it erupts and is worn by use, each cheek tooth moves forward along the jaw. The front of the tooth wears away, and as it does so the anterior enamel plates drop out one by one. At the same time, the tooth rotates in a plane parallel to the anterior-posterior orientation of the jaw, with resultant constant change in the angle between the wear surface of the tooth and the enamel plates. Thus a comparison of teeth at different stages of wear is difficult. The measurement system used in the construction of Fig. 3 represents an effort by Cooke to cancel out some of these variables.

Mammoth teeth from the Atlantic continental shelf have many plates composed of enamel that, in most specimens, is as thin as in teeth of the woolly mammoth. The ratio of number of tooth plates to tooth length is the same as in coarser-toothed specimens of woolly mammoth and in finer-toothed Columbian mammoths. However, the combination of more numerous dental plates and relatively low crowns shows that the teeth of continental-shelf mammoths differ from those of the species described. These features could reasonably belong to a grazing elephant or to one that ate the coarse forage offered by conifers. The size of the teeth indicates that the animals were small in stature, perhaps a dwarf variety of Mammuthus primigenius or of $M$. jeffersonii. However, the metric differences (Fig. 3) prevent definite assignment of the continental-shelf specimens to any of the recognized species of Mammuthus. We assign no specific name to the mammoth teeth from the continental shelf, believing that as a group they have unifying characteristics in which they differ from other populations, but we do not know enough to assign them to an existing or a new species.

Withdrawal of the water from the continental shelf, followed 10,000 to 20,000 years later by resubmergence, limits the time span of the elephant population of the shelf. The time span may have been even more limited if early man (Clovis or a related culture) caused the disappearance of elephants from the adjacent land between 11,000 and 6000 years ago (13). The mammoth population of the continental shelf is as unified in its dental characteristics as are most species of Mammuthus. The unity of the sample reinforces our conclusion, based upon study of their tooth morphology, that the specimens of continental-shelf mammoth represent a single species.

The 33 molars and one fragment of tusk from mastodons are assigned to Mammut americanum (Kerr). The distribution of the mastodon remains is not materially different from that of the mammoth (Fig. 2), but new finds from farther south may exhibit a difference in range.

Besides elephant teeth, remains of other Pleistocene land mammals have been dredged from the continental shelf off the Atlantic coast of the United States. Richards (14) listed horse, tapir, musk ox, and giant moose; we have seen or received reports of the following:

Ovibovine?, Symbos sp., USNM 23787

Left mandible of a musk ox, probably of an extinct genus; dredged by fishing vessel Aloha $64 \mathrm{~km}$ northeast of Cape Charles, Virginia $\left(37^{\circ} 30^{\prime} \mathrm{N}, 74^{\circ} 44^{\prime} \mathrm{W}\right)$, in $46 \mathrm{~m}$ of water during May 1966.

Symbos cavifrons (Leidy), PU 16340

Left frontal and horn core of an extinct musk ox; dredged by D. Leeds $64 \mathrm{~km}$ southeast of Atlantic City, New Jersey, in $60 \mathrm{~m}$ of water; given to Princeton University in 1950 .

Cervalces scotti Lydekker, PU 16342

Right metacarpal of an extinct mooselike animal; dredged from Hudson Canyon, off New York, in $160 \mathrm{~m}$ of water by T. Phillips, E. Dempsey, and F. Colona; given to Princeton University in 1950
A. S. Romer has informed us of a report by T. Barbour (15) that somewhere off Fire Island, New York, a collection of remains of extinct Patagonian mammals also lies on the bottom; it was destined for the Museum of Comparative Zoology at Harvard, but was lost when a sailing ship bound for New York was wrecked. The wreck occurred between 1874 and 1910, the period of Alexander Agassiz's activity as director and patron of the museum. When the vessel's hull disintegrates, these fossils will be scattered on the sea floor to confound future marine geologists.

Molars of mastodons and mammoths and bones of other land mammals have been recovered by fishermen from at least 40 sites on the Atlantic continental shelf. Each site is within a broad area of sand that is relict from a time of glacially lowered sea level. Also in this area, intertidal salt-marsh peat has been recovered from depths as great as 59 $\mathrm{m}$. Radiocarbon dates for these materials range back to 11,000 years ago. The number and distribution of the teeth, some of which have been found near the seaward edge of the relictsand area, indicate that mammoths and mastodons ranged the shelf in large numbers during the last 25,000 years. Various other subarctic mammals, such as musk oxen, also undoubtedly abounded. Few remains of other mammals have been recovered, probably because they are less easily identified in trawler hauls than are the large and conspicuous proboscidean teeth.

Frank C. Whitmore, JR.

U.S. Geological Survey,

Washington, D.C.

K. O. EMERY

Woods Hole Oceanographic Institution, Woods Hole, Massachusetts

H. B. S. COOKE

Department of Geology, Dalhousie

University, Halifax, Nova Scotia

Donald J. P. SwifT

Puerto Rico Nuclear Center, Mayaguez.

References and Notes

1. K. O. Emery, in Colson Symp. Bristol England April 1965 - (Butterworths, London, 1965), vol. 1.

2. By K. O. Emery, R. Wigley, A. A. Bartlett, M. Rubin, and E. S. Barghoorn.

3. W. Harrison, R. J. Malloy, G. A. Rusnak, J. Terasmae, J. Geol. 73, 201 (1965); J. C. Medcof, A. H. Clarke, Jr., J. S. Erskine, J. Fisheries Res. Board Can. 22, 631 (1965); A. S. Merrill, K. O. Emery, M. Rubin, Science 147, 398 (1965).

4. K. O. Emery, R. L. Wigley, M. Rubin, Limnol. Oceanog. Spec. 10, R 97 (1965).

5. J. M. Zeigler, S. D. Tuttle, H. J. Tasha, G. S. Giese, Bull. Geol. Soc. Amer. 75, 705 (1964).

6. J. Ewing, X. Le Pichon, M. Ewing, $J$. Geophys. Res. 68, 6303 (1963); S. T. Knott, 
H. Hoskins, R. H. Weller, Trans. Amer Geophys. Union 44, 64 (1963)

7. F. P. Shepard, Essays in Marine Geology (Univ. of Southern California Press, Los Angeles, 1963), vol. 1 .

8. J. L. Forsyth, Ohio Conservation Bull. 27(9) 16 (1963); O. P. Hay, Carnegie Inst. Publ. 322, 1 (1923); G. L. Jepsen, New Jerse State Museum Bull. 6, 10, 11 (1960)

9. W. L. Donn, W. R. Farrand, M. Ewing, J. Geol. 70(2), 206 (1962).

10. Nobuo Ikebe, Manzo Chiji, Shiro Ishida, J. Geosci. Osaka City Univ. 9(3), 47 (1966), Hiroshi Niino, personal communication, Nov. 1966; specimen in zoo at Yashima National Park, Takamatsu, Shikoku.

11. J. F. de Veen Visserij-Nieuws 18(6), 187 (1965) 12. W. R. Farrand, Science 133, 729 (1961).

13. C. V. Haynes, Jr., ibid. 145, 1408 (1964); J. B. Griffin, The Quaternary of the United States (Princeton Univ. Press, Princeton, N.J., 1965), p. 655; P. S. Martin, Nature 212, 339 (1966).

14. H. G. Richards, Bull. Geol. Soc. Amer 70(12), 1769 (1959).
15. T. Barbour, A Naturalist's Scrapbook (Harvard Univ. Press, Cambridge, Mass., 1946). 16. H. F. Osborn, Proboscidea (American Museum Press, New York, 1942), vol. 2 p. 935 .

17. We thank D. Baird (Princeton University), W. C. Childs (Linwood, N.J.), Mrs. W. J. Davis (White Marsh, Va.), R. F. Flint (Yale University), J. Hahn (Woods Hole Oceanographic Inst.), M. C. McKenna (American Museum of Natural History), M. L. Milholen (Hampton, Va.), H. G. Richards (Academy of Natural Sciences of Philadelphia), A. S. Romer (Harvard Univ.), R. L. Wigley (Bureau of Commercial Fisheries Biological Laboratory, Woods Hole, Mass.), and Dr. and Mrs. H. E. Wood II (Cape May Court House, N.J.) for specimens and data; and C. E. Ray U.S National Museum for anitically reading the manucript and identifying the script and identifying the National Museum the Woods Hole Oceanographic Institution. 25 January 1967 